\title{
SIMPLE AND SENSITIVE DETECTION FOR TRACE CHROMIUM (VI) USING ALBUMIN AS FLUORESCENCE PROBES
}

\author{
HUI-YAN KUANG, XIAO-YUN YUAN, LEI FENG, HAO-WEN HUANG, CHUN-RAN TANG, \\ KE-QIN DENG, YUN-LONG ZENG*
}

(School of Chemistry and Chemical Engineering, Hunan University of Science and Technology, Key Laboratory of Theoretical Chemistry and Molecular Simulation of Ministry of Education of China, Xiangtan 411201, PR China

\begin{abstract}
We have developed a novel method for fast determination of chromium(VI) using egg albumin(EAB) as fluorescence probe. The influence factors, including $\mathrm{pH}$, reaction time, concentration of $\mathrm{EAB}$, were investigated on the performance of the method and the optimum experimental conditions were determined. Under the optimum conditions, the relative fluorescence intensity of albumin was linearly proportional to $\mathrm{Cr}(\mathrm{VI})$ over a concentration range from $1.0 \times 10^{-7}$ to $6.0 \times 10^{-5}$ mol L ${ }^{-1}$ with a correlation coefficient of 0.9936 and a detection limit of $5.2 \mathrm{nmol} \mathrm{L}^{-1}$. This is a fast, simple, high selective and environment-friendly method, which has been employed to detect trace $\mathrm{Cr}(\mathrm{VI})$ in drinking water samples with satisfactory. The infrared spectral information indicated that the possible mechanism of fluorescence quenched may be the change of the secondary structures of EAB in the presence of $\mathrm{Cr}(\mathrm{VI})$.
\end{abstract}

Key words: Trace chromium(VI); fast analysis; egg albumin; fluorescence probe; drinking water

\section{INTRODUCTION}

In recent years, significant progress has been realized on the impact of pollution on the environment and human health. Water, food and medicine are the possible sources of contaminants such as chromium. Chromium exists in two oxidation states, $\mathrm{Cr}(\mathrm{III})$ and $\mathrm{Cr}(\mathrm{VI})$ in solution, which have contrasting physiological effects. Cr(III) is known as an essential trace element for maintaining normal physiological function. However, $\mathrm{Cr}(\mathrm{VI})$ is highly carcinogenic and mutagenic [1-3], and can cause various of clinical problems, such as immediate cardiovascular shock, negative effects on kidney, liver, and other organs [4]. Hence, the research has drawn much attention in detection of trace $\mathrm{Cr}(\mathrm{VI})$ in drinking water recently. Many new methods to detect trace $\mathrm{Cr}(\mathrm{VI})$ have been developed, including spectrophotometric method $[5,6]$, fluorescence probe method[7-9], electrochemical method $[10,11]$, ion chromatography [12], inductively coupled plasma mass spectrometry [13], inductively coupled plasma-optical emission spectrometry [14], atomic absorption spectrometry [15]. These methods need either expensive instruments or long analysis time, or consumption of a great deal of reagents [16]. Therefore, developing simple and environment-friendly method for selective, sensitive and rapid determination of trace chromium is still a great challenge.

Protein is a biodegradable and environment-friendly reagent and has widely used in biochemistry and analytical chemistry [17-19]. Egg albumin (EAB) is a cheap, environment-friendly, and egg resources are very rich (available in abundance in egg). But the research of this reagent in analytical chemistry was seldom reported. In this work, we find that EAB shows high selective for $\mathrm{Cr}(\mathrm{VI})$, and then have developed a novel method for fast determination of trace chromium(VI) based on the fluorescence quenched of EAB by $\mathrm{Cr}(\mathrm{VI})$.

\section{EXPERIMENTAL}

\subsection{Apparatus}

Fluorescence measurements were performed using Hitachi F-4500 fluorescence spectrophoto- meter (Tokyo, Japan) with a xenon discharge lamp, $1 \mathrm{~cm}$ quartz cells at room temperature. Infrared spectra and UV-visible spectra were recorded using Spectrum One Spectrophotometer and Lamaba 35 UVVis Spectrophotometer (Perkin-Elmer, American), respectively.

2.2 Reagents

Egg albumin and $\mathrm{K}_{2} \mathrm{Cr}_{2} \mathrm{O}_{7}$ (Standard Reagent) were purchased from China Pharmaceutical Group (Shanghai, China). Stock standard aqueous solution of $\mathrm{K}_{2} \mathrm{Cr}_{2} \mathrm{O}_{7}$ was prepared at concentration of $0.0050 \mathrm{M}$, and the other concentration of $\mathrm{K}_{2} \mathrm{Cr}_{2} \mathrm{O}_{7}$ was prepared by diluting the stock standard solution with double distilled water. All other chemicals used were of analytical grade without further purification. Doubly distilled water was used for all chemical procedures.

2.3 Detection of chromium(VI)

Chromium(VI) determination was carried out by successively adding 100 $\mathrm{ml}$ varying concentration of $\mathrm{Cr}(\mathrm{VI})$ or sample solution into $10 \mathrm{ml} 0.40 \mathrm{mg}$ EAB $\mathrm{KH}_{2} \mathrm{PO}_{4}-\mathrm{Na}_{2} \mathrm{HPO}_{4}$ buffer solution(PBS) solution ( $\mathrm{pH}$ 9.18). The fluorescence intensity of the solution was recorded at the peak wavelength (about $345 \mathrm{~nm}$ ). All measurements were made under room temperature.

\section{RESULTS AND DISCUSSION}

3.1 Selection of excitation wavelength

Emission and excitation spectra of $\operatorname{EAB}(a, b)$ and UV-vis absorption spectra of $\mathrm{EAB}$ and $\mathrm{K}_{2} \mathrm{Cr}_{2} \mathrm{O}_{7}(\mathrm{c}, \mathrm{d})$ are shown in figure 1, respectively. There is continuous excitation spectrum of EAB (see Fig. 1 curve b) with a maximum peak locates at $295 \mathrm{~nm}$. When the excitation is set at $295 \mathrm{~nm}$, the albumin has a broad, strong and symmetricl emission (curve a in Fig.1) with the maximum fluorescence at $345 \mathrm{~nm}$. As known, potassium dichromate absorbs UV light, which may cause the inner filter and can appear error. Hence, the characteristic of UV-vis absorption spectrum of potassium dichromate was investigated. As seen from Fig.1 (curve d), there are UV-vis absorption peaks of potassium dichromate locating at about $255 \mathrm{~nm}$ and $354 \mathrm{~nm}$. Fortunately, the absorption is very weak at the wavelength range from $295 \mathrm{~nm}$ to $315 \mathrm{~nm}$. So the fluorescence emission at $345 \mathrm{~nm}$ was used for quantitative analysis, and the excitation was set at $295 \mathrm{~nm}$ in the following experiments.

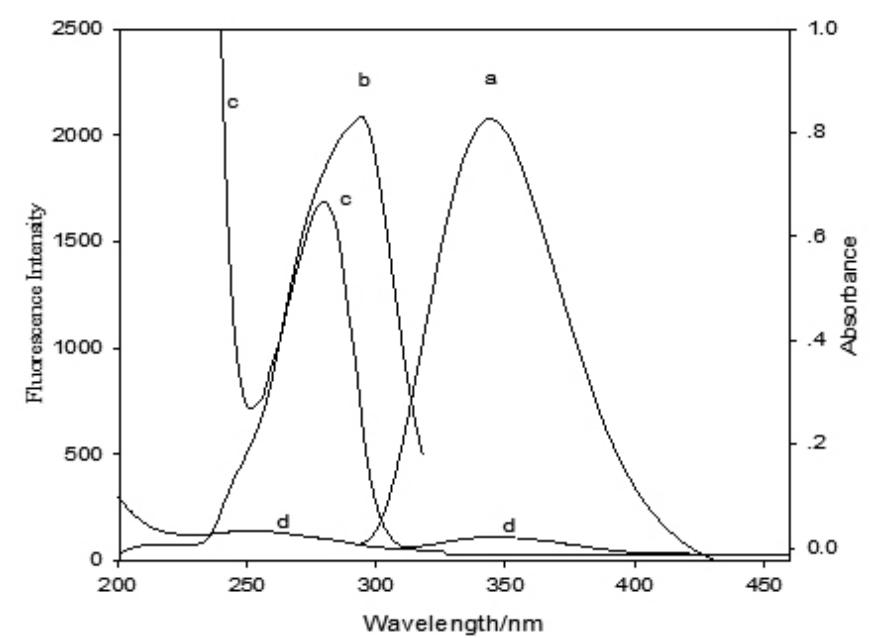

Fig. 1. Emission and excitation spectra of $\operatorname{EAB}(\mathrm{a}, \mathrm{b})$ and $\mathrm{UV}$-vis absorption spectra of EAB and $\mathrm{K}_{2} \mathrm{Cr}_{2} \mathrm{O}_{7}(\mathrm{c}, \mathrm{d})$.

Concentration, egg albumin: $50 \mathrm{mg} \mathrm{L}^{-1}$, potassium dichromate: $3.0 \mathrm{mg} \mathrm{L}^{-1}$.

3.2 Influence of ions on the fluorescence of the albumin

The effect of ions on the fluorescence intensity of EAB was studied and 
the results were shown in figure 2. It can be seen that $100 \mathrm{mmol} \mathrm{L}^{-1}$ of these relevant ions(including $\mathrm{Ba}^{2+}, \mathrm{Mg}^{2+}, \mathrm{Pb}^{2+}, \mathrm{Mn}^{2+}, \mathrm{Zn}^{2+}, \mathrm{Co}^{2+}, \mathrm{Ag}^{+}, \mathrm{Fe}^{3+}, \mathrm{Al}^{3+}$, $\mathrm{Fe}^{2+}, \mathrm{Ni}^{2+}, \mathrm{Cu}^{2+}$ and $\left.\mathrm{Cr}^{3+}\right)$ do not produce noticeable effect on the fluorescence emission $(345 \mathrm{~nm})$ of albumin except $\mathrm{Cu}^{2+}$ ion. So $\mathrm{EAB}$ fluorescence probe is very suitable for $\mathrm{Cr}(\mathrm{VI})$.

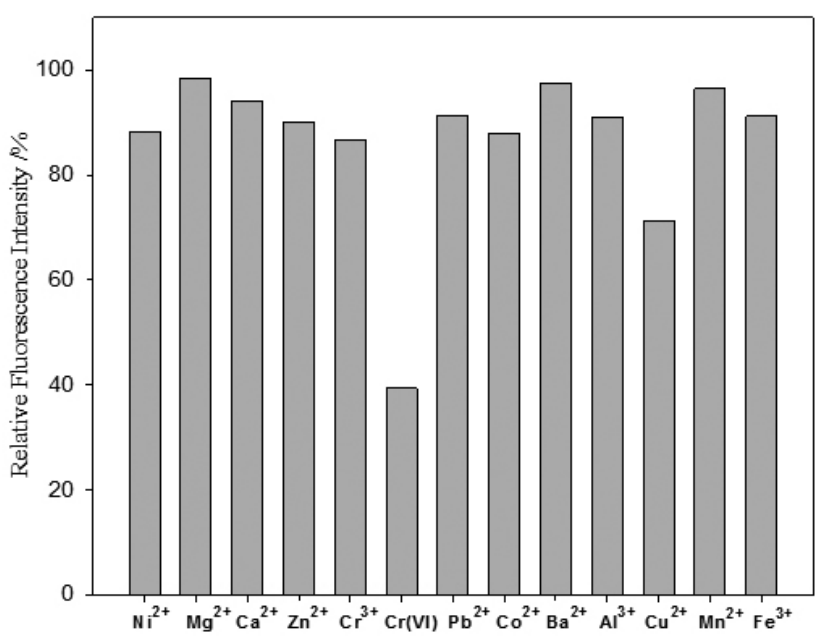

Fig. 2 Effect of ions on the fluorescence intensity of EAB, the concentrations of the cations: $100 \mu \mathrm{mol} \mathrm{L}-1$.

3.3 Influence of $\mathrm{pH}$

Buffers such as Tris- $-\mathrm{HCl}, \mathrm{KH}_{2} \mathrm{PO}-\mathrm{Na}_{2} \mathrm{~B}_{4} \mathrm{O}_{7}$ and $\mathrm{KH}_{2} \mathrm{PO}-\mathrm{Na}_{2} \mathrm{HPO}$ (PBS) were used to adjust the $\mathrm{pH}$ value of the solution, and a satisfactory result for the detection of $\mathrm{Cr}(\mathrm{VI})$ was obtained in PBS.

The influence of the solution $\mathrm{pH}$ on the fluorescence intensity of EAB was investigated in the presence of $\mathrm{Cr}(\mathrm{VI})$ in $\mathrm{pH}$ range of 6-10. When the solution of $\mathrm{pH}$ value is 9.18, the method has a wider linear concentration range and lower detection limit. Hence, $\mathrm{pH} 9.18 \mathrm{PBS}$ was used to adjust the $\mathrm{pH}$ of the solution in the following experiments.

3.4 Selection of the concentration of egg albumin

The influence of albumin concentration on the fluorescence intensity of the solution was investigated in the presence of $50 \mathrm{mmol} \mathrm{L}^{-1} \mathrm{Cr}(\mathrm{VI})$. When the concentration of EAB was $40 \mathrm{mg} \mathrm{L}^{-1}$, the change of fluorescence intensity of the solution reached the maximum(see Fig.3), which indicated that there was high sensitive to $\mathrm{Cr}(\mathrm{VI})$ assay in this albumin concentration. So this concentration of EAB was used in the following experiments.

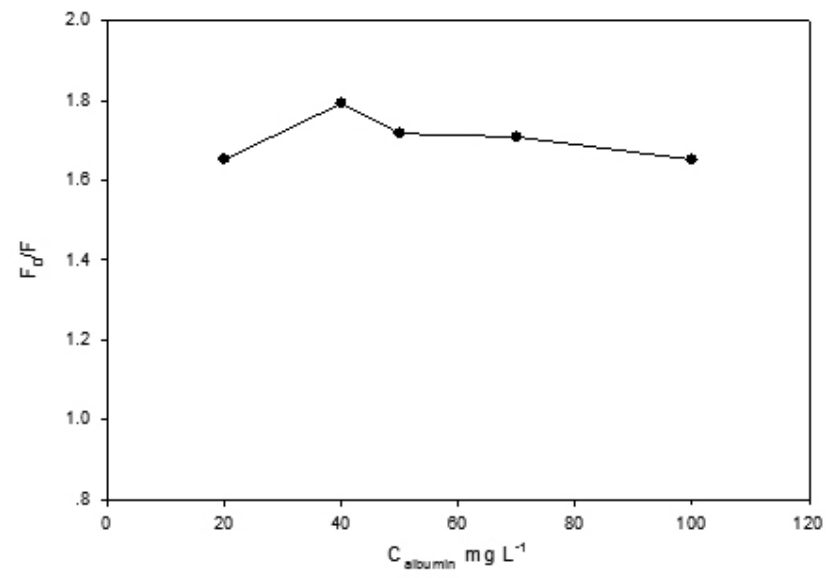

Fig.3 Effect of concentration of EAB on the quenching of the fluorescence at $50 \mu \mathrm{mol} \mathrm{L}^{-1}$ of $\mathrm{Cr}(\mathrm{VI})$.

\subsection{Influence of reaction time}

The effect of reaction time on the relative fluorescence intensity of the albumin in the presence of $\mathrm{Cr}(\mathrm{VI})(0,10,50$, and $100 \mu \mathrm{mol} / \mathrm{L}$ respectively) was investigated. As shown in Fig.4, the fluorescence intensity of EAB decreases rapidly and when $\mathrm{Cr}(\mathrm{VI})$ was added into the albumin solution. The fluorescence intensity reaches the lowest immediately and keeps unchanged more than 50 min. So the reaction time was fixed at $5 \mathrm{~min}$.

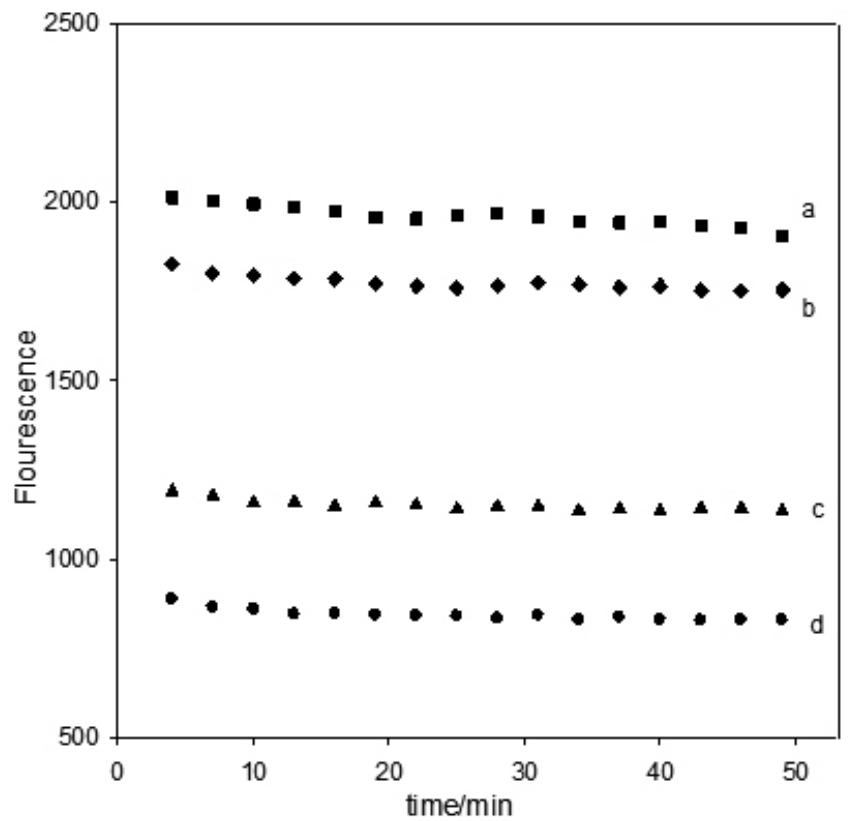

Fig. 4 Effect of reacting time on fluorescence intensity of EAB, the concentrations of $\mathrm{Cr}(\mathrm{VI})$,(a) 0 (b) 10 (c) 50 and (d) $100 \mu \mathrm{mol} \mathrm{L}^{-1}$.

3.6 Calibration curve and detection limit

Under optimum conditions, a linearity was observed (insert of Fig. 5) in the $\mathrm{Cr}(\mathrm{VI})$ concentration range from $1.0 \times 10^{-7}$ to $6.0 \times 10^{-5} \mathrm{~mol} \mathrm{~L}^{-1}$. The linear regression equation was $F_{0}-F=16.4 C+105.8$, where $F_{0}$ and $F$ are the fluorescence intensity of $\mathrm{EAB}$ at free and a given $\mathrm{Cr}(\mathrm{VI})$ concentration solution, respectively. And $C$ represents the concentration of $\mathrm{Cr}(\mathrm{VI})$ (the unit of $C$ is $\mu \mathrm{mol} \mathrm{L}^{-1}$ ), the correlation coefficient was 0.9936 . The detection limit (LOD) is defined by the equation LOD $=3 S_{0} / K$, where $S_{0}$ is the standard deviation of blank measurements (nine measurements, $\mathrm{n}=11$ ), $K$ is the slope of calibration graph. The LOD is $5.2 \times 10^{-9} \mathrm{~mol} \mathrm{~L}^{-1}$ and the relative standard deviation is $2.9 \%$ for the determination of $1.0 \times 10^{-6} \mathrm{~mol} \mathrm{~L}^{-1} \mathrm{Cr}(\mathrm{VI})(\mathrm{n}=11)$.

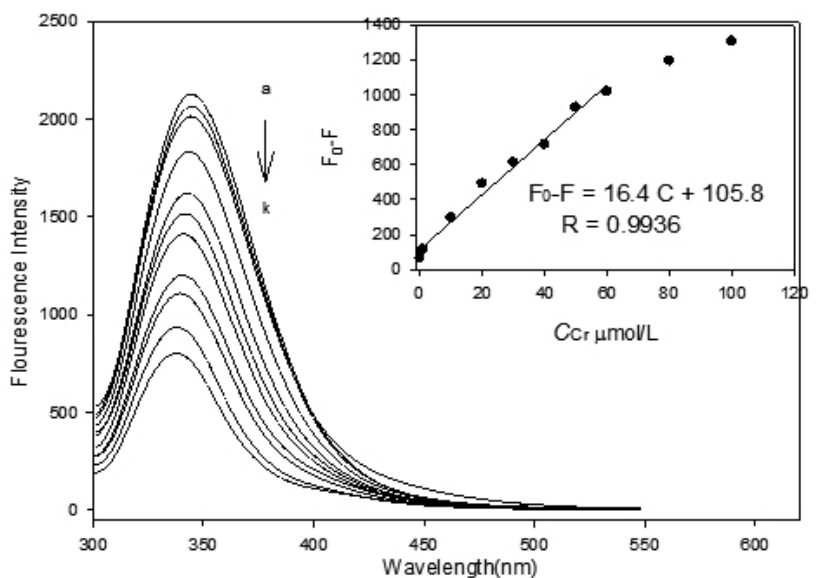

Fig.5 The fluorescence spectra of EAB in the presence of chromium (VI) at various concentrations: a) 0, b) 0.1 , c) 1 , d) 10 , e) 20 , f) 30 , g) 40 , h) 50 , i) 60 , j) 80 , k) $100 \mu \mathrm{mol} \mathrm{L}^{-1}$. Inset: the calibration curve of chromium anions $\mathrm{Cr}(\mathrm{VI})$.

Comparison between our proposed method and some methods reported recently for the determination of $\mathrm{Cr}(\mathrm{VI})$ is presented in Table 1 . The present 
method showed lower detection limit and wider linear range.

Table 1 Comparison of the present methods for $\mathrm{Cr}(\mathrm{VI})$ determination.

\begin{tabular}{|c|c|c|}
\hline Method & Linearity range & Detect limit \\
\hline Spectrophotometry [6] & $0.1-14.0 \mu \mathrm{g} \mathrm{ml}^{-1}$ & $0.01 \mu \mathrm{g} \mathrm{m}^{-1}$ \\
\hline Fluorescence quenching [7] & $3-4000 \mu \mathrm{g} \mathrm{L}^{-1}$ & $1 \mu \mathrm{g} \mathrm{L}^{-1}$ \\
\hline Fluorescence quenching [8] & $0.01-1.00 \mu \mathrm{g} \mathrm{ml}^{-1}$ & $0.008 \mu \mathrm{g} \mathrm{ml}^{-1}$ \\
\hline Fluorescence quenching [9] & $5-500 \mu \mathrm{g} \mathrm{L}^{-1}$ & $0.5 \mu \mathrm{g} \mathrm{L}^{-1}$ \\
\hline Electrochemical method [12] & $0.5-50 \mu \mathrm{M}$ & $0.1 \mu \mathrm{M}$ \\
\hline SP-RLS [20] & $40-320 \mathrm{nM}$ & $20 \mathrm{nM}$ \\
\hline FAAS method [21] & $1-40 \mu \mathrm{g} \mathrm{L}^{-1}$ & $0.8 \mu \mathrm{g} \mathrm{L}^{-1}$ \\
\hline The proposed method & $\mathbf{0 . 1}-60 \mu \mathrm{mol} \mathrm{L}^{-1}$ & $5.2 \mathrm{n} \mathrm{mol} \mathrm{L}^{-1}$ \\
\hline
\end{tabular}

3.7 Influence of common coexisting substances

As mentioned above EAB fluorescence probe is very suitable for $\mathrm{Cr}(\mathrm{VI})$, as the common metal ions do not produce any noticeable effect on the fluorescence emission of $\mathrm{EAB}$ except $\mathrm{Cu}^{2+}$ ion. Experiments showed that the interference of $\mathrm{Cu}^{2+}$ can be removed using EDTA as a masking reagent. As $\mathrm{Cr}(\mathrm{VI})$ in anion forms $\left(\mathrm{CrO}_{4}{ }^{2-}\right.$ or $\left.\mathrm{Cr}_{2} \mathrm{O}_{7}{ }^{2-}\right)$ in water, the influence of anions was also examined. The tolerance limit of some coexistence for the detection of $1.00 \mu \mathrm{mol} \mathrm{L}^{-1} \mathrm{Cr}(\mathrm{VI})$ were examined in the presence of $\operatorname{EDTA}\left(0.001 \mathrm{~mol} \mathrm{~L}^{-1}\right)$, as the relative error less than $\pm 5 \%$. The results shown that 1000 times of $\mathrm{Ca}^{2+}$, $\mathrm{SO}_{4}^{2-;} ; 500$ times of $\mathrm{Ag}^{+}, \mathrm{Mg}^{2+}, \mathrm{Ba}^{2+}, \mathrm{Ni}^{2+}, \mathrm{Zn}^{2+}, \mathrm{Co}^{2+}, \mathrm{Pb}^{2+}, \mathrm{Cr}^{3+}, \mathrm{Fe}^{3+}, \mathrm{Al}^{3+}, \mathrm{NO}_{3}^{-}$, $\mathrm{Cl}^{-} ; 300$ times of $\mathrm{Cu}^{2+}, \mathrm{Hg}^{2+}, \mathrm{Mn}^{2+}, \mathrm{CH}_{3} \mathrm{COO}^{-}, \mathrm{BrO}_{3}^{-} ; 100$ times $\mathrm{Fe}^{2+} ; 50$ times of $\mathrm{Br}^{-}$; and 20 times of $\mathrm{I}^{-}$and $\mathrm{NO}_{2}^{-}$have no interference on the determination. So this method has relatively high selectivity.

3.8 Mechanism of quenching

Generally, metal ions react with protein to form metal-protein complex, which often cause the change of the secondary structures of the protein. The FT-IR spectra of EAB and Cr(VI)-EAB are shown in Fig. 6. One can see from the infrared absorption spectrum in Fig. $6 \mathrm{~b}$ that the absorption peak at 1654 $\mathrm{cm}^{-1}$ decreases with a hyperchromic shift $\left(\right.$ about $\left.7 \mathrm{~cm}^{-1}\right)$ slightly and the relative intensity of the absorption peak at $1530 \mathrm{~cm}^{-1}$ increases compared with curve a in Fig.6. These absorption peaks are characteristic amide I and II bands from amide groups in EAB. So the information of FT-IR indicated that the formation of $\mathrm{Cr}(\mathrm{VI})-\mathrm{EAB}$ may cause the change of the secondary structures of EAB resulting the fluorescence quenched.

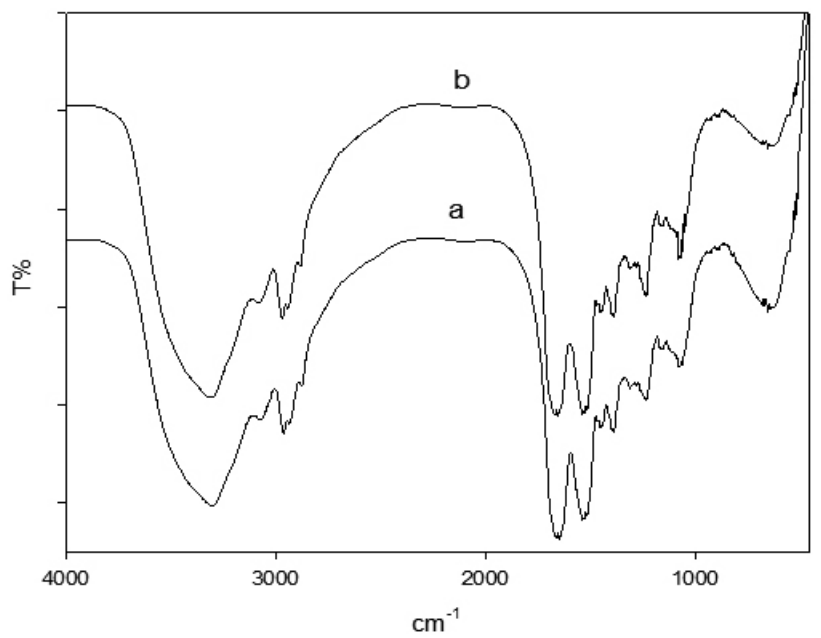

Fig.6 FT-IR spectra for EAB(a) and the complex of Cr(VI)-EAB(b).

3.9 Application of the method

Under optimal experimental conditions, the proposed method was applied to determine $\mathrm{Cr}(\mathrm{VI})$ in real samples using EDTA as a masking reagent and the results were recorded in Table 2. On the other hand, $\mathrm{Cr}(\mathrm{VI})$ in table-water, well water and the Dongting Lake water was $0.013,0.010$ and $0.046 \mathrm{mg} \mathrm{L}^{-1}$, respectively obtained by DPCI standard method [22]. As seen from Table 2, there was good agreement between the two methods, which indicate that the present method can be applied to determination of $\mathrm{Cr}(\mathrm{VI})$ in real samples.

Table 2 determination of $\mathrm{Cr}(\mathrm{VI})$ in samples.

\begin{tabular}{|c|c|c|c|c|c|}
\hline Samples & $\begin{array}{c}\text { Found } \\
\left(\mathrm{mg} \cdot \mathrm{L}^{-1}\right)\end{array}$ & $\begin{array}{c}\text { Added } \\
\left(\mathrm{mg} \cdot \mathrm{L}^{-1}\right)\end{array}$ & $\begin{array}{c}\text { Total } \\
\text { found } \\
\left(\mathrm{mg} \cdot \mathrm{L}^{-1}\right)\end{array}$ & $\begin{array}{c}\text { Recovery } \\
(\%)\end{array}$ & $\begin{array}{c}\text { RSD } \\
(\%)\end{array}$ \\
\hline Table-water & 0.012 & 0.052 & 0.067 & 105.8 & 2.8 \\
\hline Well water & 0.009 & 0.052 & 0.065 & 107.7 & 3.2 \\
\hline $\begin{array}{c}\text { The } \\
\text { Dongting } \\
\text { Lake water }\end{array}$ & 0.042 & 0.052 & 0.096 & 103.8 & 2.6 \\
\hline
\end{tabular}

\section{CONCLUSION}

In summary, we have developed a novel method to detect trace $\mathrm{Cr}(\mathrm{VI})$ using egg albumin as fluorescence probes at $\mathrm{pH}$ 9.18. The proposed method has wider linear concentration and lower detection limits compared with the other method. The common metal ions and common anions do not produce interference obviously by cooperating with masking of EDTA, and this high sensitive and selective method was successfully used to detect trace $\mathrm{Cr}(\mathrm{VI})$ in drinking water. The information of FT-IR showed that the possible physiological mechanism of fluorescence quenching may be the change of the secondary structures of $\mathrm{EAB}$ in the presence of $\mathrm{Cr}(\mathrm{VI})$. $\mathrm{EAB}$ is an environment-friendly, rich in source and cheap bio-chemical. This research will open new application of the extensive prospects bio-chemical.

\section{ACKNOWLEDGMENTS}

The authors gratefully acknowledge financial support from National Natural Science Foundation of China (No. 21475040), the State Key Laboratory for Chemo/Biosensing and Chemometrics Foundation (No.2008006), Scientific Research Fund of Hunan Provincial Education Department (No. 10K024) and the innovation Foundation of Graduate Student of Hunan University of Science and Technology (No. S130027).

\section{REFERENCES}

1.- Y.Lei, X. Qian, J. Shen, X.An, Ind. Eng. Chem. Res. 51(2012)10408-10415.

2.- M. Golonka, Polyhedron 15 (1995) 3667-3689.

3.- M. Jakubowska, J. Hazard. Mater. 176 (2010) 540-548.

4.- Z. Q. Han, L. Qi, G. Y. Shen, W. Liu, Y. Chen, Anal. Chem. 79 (2007) $5862-5868$.

5.- Y. M. Scindia, A. K. Pandey, A.V. R. Reddy, S. B. Manohar, Anal. Chem. 74(2002) 4204-4212.

6.- D.G. Themelis, F. S. Kika, A. Economou, Talanta 69 (2006) 615-620.

7.- L. Zhang, C. Xu, B. Li, Microchim. Acta 166 (2009) 61-68.

8.- S. Hong, H. Chen, L. Wang, L. Wang, Spectrochim. Acta Part A 70(2008) $449-453$.

9.- H. Zhang, Q. Liu, T. Wang, Z. Yun, G. Li, J. Liu, G. Jiang, Anal. Chim. Acta 770 (2013) 140-146.

10.- S. J. Xing, H. Xu, G. Y. Shi, J. S. Chen, L. P. Zeng, L. T. Jin, Electroanalysis 21 (2009) 1678-1684

11.- J. Li, J. C. Zhang, H. Wei, E. K. Wang, Analyst 134(2009) 273-277.

12.- M. C. Tsai, P. Y. Chen, Talanta 76(2008)533-539.

13.- B. Wen, X.Q. Sgan, J. Lian, Talanta 56 (2002) 681-687.

14.- J. L. Manzoor, F. Shemiranif, J. Anal. At. Spectrum. 10 (1995) 881-883.

15.- K. Kiran, K. S. Kumar, B. Prasad, J. Hazard. Mater. 150 (2008) 582-586.

16.- V. Gómez, M.P. Callao, Trends Anal. Chem. 25 (2006) 1006-1015.

17.- J. Liu, J. Tian, J. Zhang, Z. Hu, X. Chen, Anal. Bioanal. Chem. 376(2003) 864-867.

18.- M. Liu, Z. J. Lim, Y. Y. Gwee, A. Levina, Peter A. Lay, Angew. Chem. Int. Ed. 49(2010)1661-1664.

19.- C. J. Tan, H. G. Chua, K. H. Ker, Y. W. Tong, Anal. Chem. 80 (2008) 683-692.

20.- Z. Han, L. Qi, G. Shen, W. Liu, Y. Chen, Anal. Chem. 79(2007)58625868.

21.- A.N. Anthemidis, G.A. Zachariadis, J.S. Kougoulis, J.A. Stratis, Talanta 57(2002)15-22.

22.- The national standards in People's Republic of China. GB 8538.19(2008)1467-1487. 